\title{
Teaching Oral English In Indonesian EFL Contexts During Globalized Challenging Time
}

\author{
Amirullah Abduh', Rosmaladewi' ${ }^{2}$, Murni Mahmud ${ }^{3}$ \\ Universitas Negeri Makassar, Indonesia',3 \\ Politeknik Pertanian Negeri Pangkajene Kepulauan, Indonesia ${ }^{2}$ \\ Email: rosmaladewi@polipangkep.ac.id²
}

Submitted: 08/01/2021

Revised: 17/01/2021

Accepted: 28/01/2021

E-ISSN : 2579-4574

P-ISSN : 2549-7359

\begin{abstract}
This paper addresses the limited studies on Oral English (OE) worldwide and the absence of OE research publications from Indonesian contexts. This study aims to fill this knowledge gap. This 6-month research project was undertaken in the Department of English Education at one of the public universities in Makassar, Indonesia. Out of 100 students, 30 student participants and 3 lecturers consented to engage voluntarily in the project. The data from questionnaires were analyzed via Ms. Excel's quantitative analysis thematically. The study indicates that students' reflections on strategies of teaching OE: appropriate topic for presentation, logical sequence of presented information, and acknowledge the source of teaching materials. This study has the implication for the teaching of $\mathrm{OE}$ in other similar geographical contexts and settings and can be useful strategies for OE teachers and practitioners.
\end{abstract}

Keywords: Perceptions, Students, Strategies, Teaching Oral English, EFL

https://ojs.unm.ac.id/eralingua

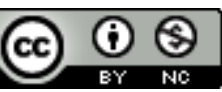

This work is licensed under a Creative Commons Attribution-NonCommercial 4.0 International License 


\section{INTRODUCTION}

In most of the oral English language teaching, the onus of Oral English (OE) programs is still placed as periphery in language learning and teaching. Students receive not sufficient training in the teaching of $\mathrm{OE}$. During speaking subjects, they are not allowed to extend their $\mathrm{OE}$, but they usually teach textbooks, which adopt a comprehension approach (Cheen, 2008). This experience may affect how students OE competency in their natural environment and encounter difficulties in facing OE tests. It is no wonder that in most of the language classrooms, the teaching of OE focuses primarily on pronunciation and developing vocabulary without doing learners' learning needs analysis and students' engagement via OE. This traditional OE instruction is prevalent in most Asian language classrooms and Indonesia is no exception (Widodo \& Rozak, 2016). For this reason, it is important to engage students with OE experience via the teaching of $O E$ via different strategies including presentation, face to face interviews, and discussions. As many teachers use these strategies as a medium for teaching English, this case is worthy of closer empirical investigation.

In the implementation, teachers face several problems related to OE. First, the limited teaching hours allocated for OE, which consequently there is limited time to practice OE. Second, students seem passive so it doesn't encourage students to participate actively in activities of OE. Third, the course of OE is offered in much higher education and is optional so that students have opted it out of the subject (Yang, \& Xiao, 2019). They suggest some ways of improving the teaching of OE including the multi-modal of resources and strategies to teach OE at college levels. Besides, some researchers have indicated the limited areas of research in $O E$.

Studies in teaching English in Indonesia has been covered in several areas. For example, Ramly and Abduh (2018) explored assessment strategies for both oral and written languages in Indonesia; Abduh (2018) investigated the factors influencing the implementation of bilingual education in higher education; Abduh, Rosmaladewi, and Basri (2018) explored awareness and commitment of Indonesian higher education for Internationalization and the roles of OE in international levels; Abduh and Rosmaladewi (2017) analyzed the importance of vocabulary levels including for the OE proficiency, and Abduh and Rosmaladewi (2018) studied the strategies of promoting intercultural competence in bilingual and English language teaching contexts. From the above studies, they concentrate on English language teaching in general with a particular focus on OE. Hence, however, little attention has been paid to strategies of teaching $\mathrm{OE}$. Therefore, this study aims to fill this knowledge gap. This article aims to explore students' perceptions and reflections on teaching OE and its challenges.

This study is the significance for teachers of English who are active promoters and facilitators in teaching $\mathrm{OE}$. The following section covers the literature review, methodology, findings, discussions, and conclusion. 


\section{Concept of OE}

$\mathrm{OE}$ is the competency of oral production in English. OE relates to the development of oral communication abilities which the meaningful communicative interactions (Sandlund, Sundqvist, \& Nyroos, 2016). The meaningful interaction means the use of $\mathrm{OE}$ can facilitate the flows of communication so there is a mutual understanding of the topics discussed. The key concept of OE focuses on the active roles of students, while teachers act as mediators and facilitators. Active roles include the attitude and perceptions of students to engage and participate actively in OE activities and exercises. Liu (2013) characterizes the roles of students in OE as demonstrators, conductors, directors, and commentators. As demonstrators, students exhibit their abilities to use oral English both through guided activities and free activities. As conductors, they facilitate the implementation of $\mathrm{OE}$, bridge the flows of activities, and mediates the improvement of $\mathrm{OE}$ competencies. As directors, they involve in design and create the OE program and activities so that participants feel enjoyment and participate actively in the program. As commentators, students can provide their input and observe critically to comment how successful the activities or not in the context of OE.

\section{Previous related studies on OE}

A burgeoning interest in the study of $\mathrm{OE}$ is evidenced by recent article publications in the past five years. Although several scholars (Chen, Chuen, Goh, Routledge, \& Taylor, 2011; Friginal, 2013; Ockey, 2014; Sandlund et al., 2016; Li, 2019) have advocated and placed emphasis on the need for OE to be part of research discourses, there is still a small body of previous research on the OE. These five previous studies become the underpinning research for this paper.

A more recent study conducted by Sandlund, Sundqvist, \& Nyroos (2016) on reviewing previous studies related to $\mathrm{OE}$. They reviewed all related databases including Modern Language Association/MLA, Education Resources Information Center/ERIC, and Linguistics and Language Behavior Abstracts/LLB and google scholars. They indicate that (1) prevalence of studies of the OPI format, but a growing research base on paired and group tests, (2) an absence of oral test studies in discourse journals, and (3) an emphasis on assessment, validation, and rater perspectives, as opposed to detailed analyses of interaction in L2 tests.

Second, Ockey (2014) looked into the impact of uninterrupted discussion to test the OE competence of test-takers. This study was designed to provide English support to students who were completing international MBA degrees in an English-medium university in Japan. The test was administered at the end of the 8-week program, the 12 test-takers knew each other fairly well because they had studied together in classes of 12 for 15 hours per week. The findings suggest that the group oral may be appropriate for assessing L2 oral ability as well as content knowledge of a particular field of study. Third, Friginal (2013) investigated the development and use of an oral performance assessment instrument to evaluate Filipino agents' customer service transactions with 
callers from the United States (US). This longitudinal case study employing qualitative observation of language training and customer service support practices of Philippinebased agents. Using the assessment instrument that was adapted from the Melbourne Medical Students' Diagnostic Speaking Scale containing task criteria and linguistic criteria, this study used 100 participants with convenient samplings. The finding suggests that the initial results of this case study indicate that the assessment of speaking ability in Philippine call centers can benefit from ESP/EOP theories and approaches. The study recommends that people working in the call center industry may achieve a higher level of English oral proficiency because of the regular practices they encounter during their works.

Fourth, Chen (2011)also investigated difficulties that teachers encounter in teaching oral English in higher education in English as a foreign language (EFL) context. The study used open-ended question surveys and semi-structured interviews with 331 EFL teachers from 44 universities in 22 cities across China. 30 teachers were interviewed. The findings showed that apart from external constraints such as large class sizes and a lack of teaching resources, EFL teachers are frustrated by their low self-efficacy concerning oral English proficiency and inadequate pedagogical knowledge. Most teachers expressed eagerness to receive training in how to design and implement effective tasks to motivate students' engagement in oral English activities. She recommends that a series of intensive English training can strengthen teachers' capacities and capabilities in English proficiency.

Fifth, Li (2019) investigated the roles of metacognition in the process and production of OE in college students. LI conducted a study on exploring selfassessment, thinking, and cognition as the basic framework of metacognition concerning college students' oral English. The study used mathematical modeling to portray the improvement of oral improvement in pronunciation. The study recommends that using algorithm mathematical modeling can exhibit the development of OE particularly pronunciation elements and it is found effective strategies to track the $\mathrm{OE}$ at university levels. Besides, the roles of self-metacognition assists in the development of OE elements in this study.

Even though the reported studies above show positive and convincing evidence regarding the OE proficiency, there is still the need for examining the strategies of teaching OE. So far, no empirical endeavor has looked at strategies of teaching OE. To fill this gap, the present study attempts to continue the scholarship of OE.

\section{RESEARCH METHOD}

\section{Research questions}

The present study was guided by the following research questions: What are students' reflections on the use of PowerPoint presentations (PPT), face to face interviews, and discussions to teach Oral English? 


\section{Research design, context, and participants}

This is a case study research approach (Yin, 2009) with action learning. This 4month research project was undertaken in the Department of English Education at one of the public universities in Makassar, Indonesia. Out of 100 students, 30 participants consented to engage voluntarily in the project. They were well-informed of the project and duly signed a consent form before they participated in this project. The participants were multilingual with competencies in Javanese, Buginese, Macassan, and Bahasa Indonesia. Ranging from 19 to 25 years old, the students were of intermediate-level language learners. The participants engaged actively in the current project until the completion of the project.

\section{Procedures}

The project began from March to June 2017. Informed by the OE design, throughout the project, the participants engaged in the following tasks.

1. Modeling: Participants in this study were assigned to observe how to use PPT to teach OE. One of the authors in this study served as a teacher for this project demonstrating how to use PPT effectively; how to complete and discuss OE in groups; and how to engage in group discussion.

2. Self-selection of oral English topics: The participants were allowed to choose their own OE topics based on a decision made in groups. By self-selecting listening materials or texts, they could see OE as a personal activity. This was to build student teachers' autonomy to select spoken texts at their convenience or based on their listening needs. Certainly, they could use the resources available (Widodo \& Rozak, 2016).

3. Group presentation and discussion: The participants were asked to view present a topic they choose for approximately 15-20 minutes. While listening to group presentation, they discussed what they learned and possible challenges and concerns.

4. Self-reflection and evaluation: Over the project, the students were asked to selfreflection on their OE progress at least every week.

5. Lecturers' evaluation: at the end of the project, lecturers were asked to provide an overall assessment of the projects.

\section{Data analysis}

The data from the Likert scale questionnaire were analyzed via Ms. Excel's quantitative analysis. The process of quantities analysis includes the collection of all data, the categorization of data, coding, and the transfer of quantitative data into the stage of writing. 


\section{Findings and Discussions}

\section{Organization of Oral English Presentation}

Students' perceptions of the organization of oral English teaching via PowerPoint included three important elements: appropriate topic for a presentation, logical sequence of presented information, and acknowledge the source of teaching materials. Most students highly appreciate that the organization of oral English teaching materials were well organized and presented in terms of an appropriate topic for presentation (57\%), logical sequence of presented information (43\%), and acknowledge the source of teaching materials (43\%). There was only a small proportion of students who viewed that using PPT to teach oral English had no difference from using other teaching methods (14\%). The students'perceptions of the organization of $\mathrm{OE}$ teaching is in Figure (1) below.

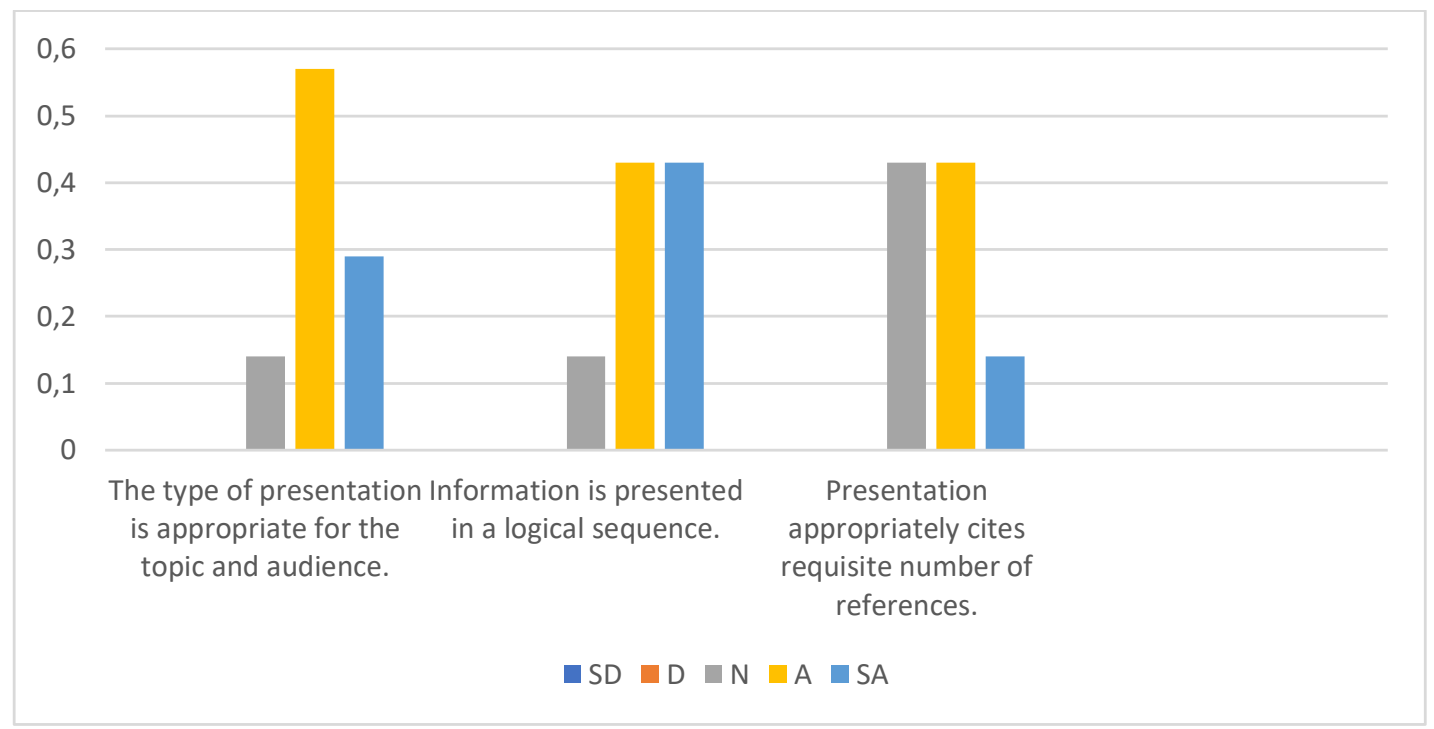

Figure 1. Organization of oral English presentation

Note: SD: Strongly Disagree, D: Disagree, N: Neutral, A: Agree, SA: Strongly Agree

The organization's OE presentation is influenced by creators and designers of the activities. The design of OE activities, like Liu (2013) argues, is a very important step in establishing the interest and the attitudes of students so that they can feel enjoyment and participate actively in the program. The feeling of enjoyment and the motivation to fully participate in the program is also influenced by the roles of selfmetacognition in the teaching of oral English ( $\mathrm{Li}, 2019)$. Besides, students 'involvement in the process of designing and development of OE presentation is triggered by several elements: language ability of students, the topical ability of students, and affective factors (Leong \& Ahmadi, 2017). Moreover, the ability to fully participate in designing 
the effective OE presentation is affected by the psychological factors: the self-esteem and the positive feeling in their involvement in the activities (Ariyanti, 2016).

From the discussion, it is noted that the strategies to create an effective, interactive, and interesting $\mathrm{OE}$ presentation in the classroom rely on the knowledge, skills, and psychological factors of the designers. Knowledge means the priorknowledge of the creators possess that they bring into effect to the creation of OE presentation. Skills relate to their ability to produce OE performance that impacts the development of OE activities. Finally, the psychological factors related to the feeling of enjoyment and encouragement to fully active in OE activities. The implication for teaching and learning is that it is crucial for teachers involving in OE to prepare an effective, interesting, and interactive presentation that suit the need and the level of participants in OE programs. For students, they are required to read any preparation materials for OE programs so that they can be engaged actively with other participants, demonstrate their ability, perform at their best level, and improve their OE competence during the programs.

\section{Quality of content of the presentation}

The quality of the content of the presentation was perceived by students based on these following elements: Introduction is attention-getting and provides clues for the rest of teaching materials, presentation is defined key information, the presentation contained accurate information, teaching materials are relevant to audiences, the appropriate amount of teaching materials, and it ends with summarizing key points and skills (Figure 2).

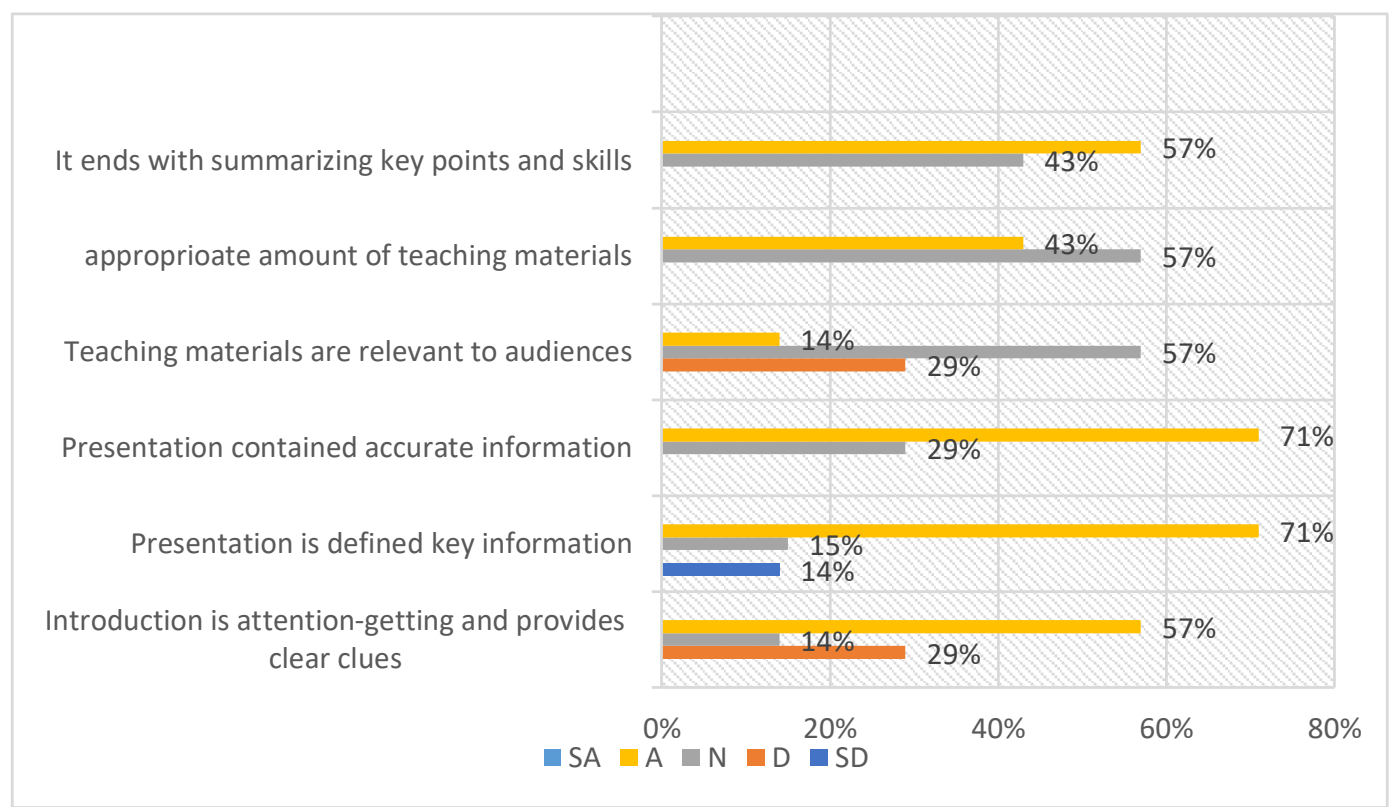

Figure 2. Content quality of oral English presentation 
Figure 2 indicates that the majority of students believe that the content quality of teaching oral English via PPT (PowerPoint Presentation) was high. It was highlighted in the five key elements: the introduction is attention-getting and provides clues for the rest of teaching materials, presentation is defined key information, the presentation contained accurate information, teaching materials are relevant to audiences, an appropriate amount of teaching materials, and it ends with summarizing key points and skills. The only small number of students perceived that teaching oral English via PPT was quite similar to other teaching media.

The goal of content in oral English is to improve students' communicative skills so they can convey the message effectively to listeners or other participants. Figure 2 indicates the criteria of effective teaching contents: authentic, accurate, and relevant materials to the need and demands of participants. Kayi (2006) points out that providing opportunities for participants to speak using authentic materials in a rich collaborative and meaningful environment can help students improve their target language competence. Thus, the target language competence is meaningful when it can contribute to the success of students in the learning and later in every phase of their life.

Concerning accurate content, it relates to the level of students and challenges students' oral English levels. The accurate contents aim to assist students to improve their vocabulary knowledge and grammar repertoire and improve their pronunciation (Hinkel, 2018). Besides, the accurate contents of OE can enhance students' pragmatic and cultural competence because speaking involves the accuracy of context and use and the accuracy of cultural contents of OE materials. Hinkel (2018) further ads that students can express the accuracy of contents culturally can be measured by the way they express the key elements of communication and social functions of the language.

The content of OE presentation and activities ends with a summary of key points. Furui, Kikuchi, Shinnaka, and Hori (2004) comment that the summary of the key points has three purposes: 1) it helps participants to review the contents that have been discussed; 2) it assist participants to point out the most interesting parts of the contents so that they review again in other times, and 3) they can retrieve the missing parts of the information. They further argue that the summary of contents can be done via texts or media. In this case study, the summary of the OE contents is presented via visual media that are visible and interesting for the participants in this study.

One of the key measurements of the relevant contents of the OE presentation is it drags the attention of the participants so that they keep their motivation during the lessons and find it relevant for the later phase of their lives. The relevant contents of OE have several interpretations of meaning: it meets learners' needs and expectations (Haerazi, Irwansyah, Juanda, \& Azis, 2018); it influences the experiences of learners in the pedagogical environments and raises participants 'awareness (Lázár, 2005); it affects positive perceptions of participants in terms of high levels of concentration, effort, enjoyment, and progress (Bower, 2019) and it challenges participants, technically, intellectually, and morally (German, Gronbeck, Ehninger, \& Monroe, 2016). 
The implication for teaching and learning OE through accurate, authentic, and relevant content is that the combinations of these elements can establish the trust of the participants to keep their motivations and spirit to be part of the OE programs. Every educator should consider creating the most interesting and authentic materials so that participants can engage in the social design communication environment and produce meaningful communication repertories. Any contents that encourage participants physically, physiologically, intellectually, and morally are essential elements for the teaching of $\mathrm{OE}$ in many different contexts particularly in the context of English as a foreign language like in Indonesia.

\section{Quality of verbal and non-verbal communications}

Students' perceived that the quality of non-verbal communication when teaching oral English via PPT included speaker maintained eye contact, the speaker used appropriate gestures, and the speaker showed engaging and inviting presence. On the other hand, the quality of verbal communication is viewed from confident and clear voice; delivery is poised, control and smooth; and good language skills and pronunciation (Table 1).

Table 1. Quality of verbal and non-verbal communications

\begin{tabular}{|c|c|c|c|c|c|c|}
\hline \multirow{4}{*}{ 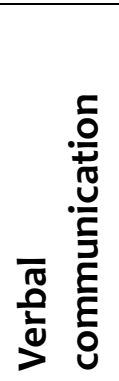 } & Elements & SD & D & $\mathbf{N}$ & A & SA \\
\hline & Confident and clear voice & - & - & - & $57 \%$ & $43 \%$ \\
\hline & $\begin{array}{l}\text { delivery is poised, control } \\
\text { and smooth }\end{array}$ & - & - & - & $43 \%$ & $57 \%$ \\
\hline & $\begin{array}{l}\text { good language skills and } \\
\text { pronunciation }\end{array}$ & - & - & $14 \%$ & $57 \%$ & $29 \%$ \\
\hline \multirow{3}{*}{ 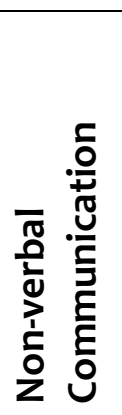 } & $\begin{array}{l}\text { Speaker maintains eye } \\
\text { contact }\end{array}$ & - & - & $42 \%$ & $29 \%$ & $29 \%$ \\
\hline & $\begin{array}{l}\text { Speaker used appropriate } \\
\text { gestures }\end{array}$ & - & - & - & $57 \%$ & $43 \%$ \\
\hline & $\begin{array}{l}\text { The speaker showed } \\
\text { engaging and inviting } \\
\text { presence }\end{array}$ & - & - & $57 \%$ & $29 \%$ & $14 \%$ \\
\hline
\end{tabular}

Table 1 indicates that there was a different quality of verbal and non-verbal communication in teaching oral English via PPT. Most students agreed that the quality of verbal communication higher and more acceptable than the quality of non-verbal communication. The reason for this was due to verbal communication helped students to decipher teaching materials easily since they concentrated to improve their language skills. It was compared to the non-verbal communication used in the teaching of oral English. 
The quality of verbal communication for OE classroom environment is important in many ways. The verbal communication provides clues and guidance for students prior the practice of OE activities. Verbal communication involves the sharing and exchange information among individuals (Fatima, 2020) and between teachers and students so that the aim of the teaching can reach the target or the objectives. Thus, verbal communication includes the use of words and sentences to express the content of the OE teaching and meaning so that participants can comprehend the content well.

One of the verbal communication elements is the quality of voice of teachers during the teaching and learning process. Teachers' tone of voices has a high positive impact of the teaching environment atmosphere (Kahlenberg, \& Potter, 2014), and teachers' voice affects the learning comprehension of students and psychological mood of the students during the teaching and learning (Södersten, Granqvist, Hammarberg, \& Szabo, 2002). Thus the quality of teachers' tone of voice in the context of OE teaching has been viewed positively by students because most answers agree and strongly agree for the teachers 'voices in OE programs. Maintaining the quality of voices is challenging for every teacher since they have long hours of teaching. Consequently, the quality of voice in verbal communication can influence the delivery phase and the smoothness of teaching especially in the contexts of foreign language teaching settings.

On the other hand, the quality of non-verbal communication is high in this study. The reasons why the quality of no-verbal communications assist the success of teaching $\mathrm{OE}$ in this study are eye contacts and gestures signify motivation and concentration, shows keeping attention to the subjects, help students better comprehend the topics, a means of emphasis, shows confidence and produce better oral English (Zeki, 2009). Zeki further adds that facial expressions and gestures show the sources of motivation, enthusiasm, and active participation in classrooms, and it reflects the mood of the teachers. This shows the importance of the quality of nonverbal communication in the teaching of OE where English as a foreign language.

The impact of the good quality non-verbal communication when teaching can be seen from various aspects. Psychologically, teachers can express their feelings and emotion bluntly through non-verbal communications. Educationally, students in this study show their appreciation for the quality of non-verbal communication used by teachers during the $\mathrm{OE}$ activities in the classroom environment. Bambaeeroo and Shokrpour (2017) argue that there is a strong positive correlation between the better performance of students in the classroom atmosphere and the appropriate use of nonverbal communication in educational contexts. Thus, the non-verbal communication used by teachers can stimulate the senses of humor, fun, and enjoyment (Bambaeeroo \& Shokrpour, 2017) for participants, which consequently increase the peace, security, and mutually respectful relationship between teachers and students. In turn, it triggers the improvement of the output quality of teaching OE in EFL contexts. 


\section{CONCLUSION}

Students' perceptions of the organization of oral English teaching via PowerPoint included three important elements: Organization of oral English presentation: appropriate topic for a presentation, logical sequence of presented information, and acknowledge the source of teaching materials. Most students highly appreciate that the organization of oral English teaching materials was well organized and presented in terms of an appropriate topic for presentation, logical sequence of presented information, and acknowledge the source of teaching materials. There was only a small proportion of students who viewed that using PPT to teach oral English had no different from using other teaching methods.

Quality of content of the presentation: it encompasses psychological and physical clues for students, the format of the presented information, accurate information, authentic materials, appropriate proportion amount of materials, and ends with highlighting important points. These key essential elements enhance the quality of teaching of $\mathrm{OE}$ where English is a foreign language. Concerning the quality of verbal and non-verbal communications, they influence the delivery of materials including phase, smoothness, and voices. Both nonverbal and verbal communication influence students psychologically and intellectually. They influence the nuance of teaching and the mode delivery of teaching $O E$.

Further research is important to enhance educators' and researchers' understanding of $\mathrm{OE}$ in many different contexts with very larger populations. Future research using the mix-method design is encouraged to conduct since such types of studies within the context of $\mathrm{OE}$ is limited. The research within different geographical locations is necessary to perform to compare the current result of studies and future studies. This current study contributes to a better understanding of OE within the context of developing countries and English is considered a foreign language.

\section{REFERENCES}

Abduh, A. (2018). Lecturers' perceptions on factors influencing the implementation of bilingual instruction in Indonesian universities. Journal of Applied Research in Higher Education, 10(3), 206-216.

Abduh, A., \& Rosmaladewi, R. (2017). Taking the Lextutor on-line tool to examine students' vocabulary level in business English students. World Transactions on Engineering and Technology Education, 15(03), 283-286.

Abduh, A., \& Rosmaladewi, R. (2018). Promoting Intercultural Competence in Bilingual Programs in Indonesia. SAGE Open, 8(3), 1-7. https://doi.org/10.1177/2158244018788616

Abduh, A., Rosmaladewi, R., \& Basri, M. (2018). Internationalization Awareness and Commitment of Indonesian Higher Education. New Educational Review, 51(1), 162171. https://doi.org/DOI: 10.15804/tner.2017.50.4.13 
Ariyanti, A (2016). Psychological Factors Affecting EFL Students' Speaking Performance. Asian TEFL, 1(1), 77-88

Bambaeeroo, F., \& Shokrpour, N. (2017). The impact of the teachers' non-verbal communication on success in teaching. Journal of advances in medical education \& professionalism, 5(2), 51-59.

Bower, K. (2019). 'Speaking French alive': learner perspectives on their motivation in Content and Language Integrated Learning in England. Innovation in Language Learning and Teaching, 13(1), 45-60.

Chen Y-M. (2008). Learning to self-assess oral performance in English: A longitudinal case study. Language Teaching Research. 12(2):235-262. doi:10.1177/1362168807086293

Chen, Z., Chuen, C., Goh, M., Routledge, F., \& Taylor, C. (2011). Teaching oral English in higher education : challenges to EFL teachers, 16, 333-345.

Fatima, N. (2020). Architecture Pedagogy Focussing on Verbal Communication Skills of Students in Design Studio. Studies in Indian Place Names, 40(10), 45-61.

Friginal, E. (2013). English for Specific Purposes Evaluation of oral performance in outsourced call centres : An exploratory case study. English for Specific Purposes, 32(1), 25-35. https://doi.org/10.1016/j.esp.2012.06.002

Furui, S., Kikuchi, T., Shinnaka, Y., \& Hori, C. (2004). Speech-to-text and speech-tospeech summarization of spontaneous speech. IEEE Transactions on Speech and Audio Processing, 12(4), 401-408.

German, K. M., Gronbeck, B. E., Ehninger, D., \& Monroe, A. H. (2016). Principles of public speaking. London and New York: Routledge.

Haerazi, H., Irwansyah, D., Juanda, J., \& Azis, Y. A. (2018). Incorporating intercultural competences in developing English materials for writing classes. Journal of Language Teaching and Research, 9(3), 540-547.

Hinkel, E. (2018). Teaching speaking in integrated-skills classes. In M. Christison and Broady (Eds), The TESOL Encyclopedia of English language teaching, (pp. 1-6). New York: John Wiley \& Sons

Kahlenberg, R. D., \& Potter, H. (2014). Why Teacher Voice Matters. American Educator, 38(4), 6-11

Kayi, H (2006). Teaching Speaking: Activities to Promote Speaking in a Second Language. The Internet TESL Journal, 12 (11), 1-5

Lázár, I. (2005). Incorporating intercultural communicative competence in language teaching education. Kapfenberg: Council of Europe. 
Leong L, Ahmadi S M. (2017). An Analysis of Factors Influencing Learners' English Speaking Skill. International Journal of Research in English Education, 2 (1), 31-41.

$\mathrm{Li}, \mathrm{X}$. (2019). Characteristics and rules of college English education based on cognitive process simulation, Cognitive Systems Research, 57, 11-19. https://doi.org/10.1016/j.cogsys.2018.09.014.

Liu, W. (2013). Role of Teachers in Oral English Teaching. In Proceedings of the International Conference on Information Engineering and Applications (pp. 13-19). London: Springer-Verlag. https://doi.org/10.1007/978-1-4471-4853-1

Ockey, G. J. (2014). English for Specific Purposes the potential of the L2 group oral to elicit discourse with a mutual contingency pattern and afford equal speaking rights in an ESP context. English for Specific Purposes, 35, 17-29. https://doi.org/10.1016/j.esp.2013.11.003

Ramly, R., \& Abduh, A. (2018). Exploring Cognitive Concepts in the National Assessment of the Indonesian Language. The New Educational Review, 53(3), 142-152.

Sandlund, E., Sundqvist, P., \& Nyroos, L. (2016). Testing L2 Talk : A Review of Empirical Studies on Second-Language Oral Proficiency Testing. Language and Linguistics Compass, 10(1), 14-29.

Södersten, M., Granqvist, S., Hammarberg, B., \& Szabo, A. (2002). Vocal behavior and vocal loading factors for preschool teachers at work studied with binaural DAT recordings. Journal of Voice, 16(3), 356-371.

Widodo, H. P., \& Rozak, R. R. (2016). Engaging Student Teachers in Collaborative and Reflective Online Video-Assisted Extensive Listening in an Indonesian Initial Teacher Education ( ITE ) Context. Electronic Journal of Foreign Language Teaching, 13(2), 229-244.

Yang, Y. and Xiao, L. (2019). The Construction of College Oral English Teaching Model Based on Multimodal Perspective. Creative Education, 10 (1), 423-428. doi: 10.4236/ce.2019.102030.

Yin, R. K. (2009). Case study research: design and methods. Applied social research methods series. Los Angeles: Sage Publications. https://doi.org/10.1097/FCH.ob013e31822ddage

Zeki, C. P. (2009). The importance of non-verbal communication in classroom management. Procedia-Social and Behavioral Sciences, 1(1), 1443-1449. 